\title{
O ABUSO PROCESSUAL NA COLABORAÇÃO (DELAÇÃO) PREMIADA: UMA VISÃO DO INSTITUTO SOB A ÓPTICA DO PRINCÍPIO DA BOA-FÉ OBJETIVA
}

THE PROCEDURAL ABUSE IN COLLABORATION AWARD (PLEA BARGAIN): A VISION OF THE INSTITUTE FROM THE POINT OF VIEW OF THE PRINCIPLE OF OBJECTIVE GOOD FAITH

Marcio dos Santos Alencar Freitas Mestrando de Direito Constitucional e Ciências Políticas pela Universidade de Fortaleza (UNIFOR). Bolsista Capes Brasil. Membro do Laboratório de Ciências Criminais (LACRIM) UNIFOR. Fortaleza/CE. E-mail: marcioalencar_1@hotmail.com

Nestor Eduardo Araruna Santiago Doutor em Direito Tributário (2005), com estágio PósDoutoral em Direito pela Universidade do Minho, Portugal (2016); Mestre (2000) e Especialista (2000) em Ciências Penais pela Universidade Federal de Minas Gerais (UFMG). Professor Titular do Programa de Pós-Graduação Stricto Sensu em Direito Constitucional e do Curso de Graduação em Direito da Universidade de Fortaleza (UNIFOR). Líder do Grupo de Pesquisa "Tutela penal e processual penal dos direitos e garantias fundamentais" (Unifor), vinculado ao Laboratório de Ciências Crminais (LACRIM - Unifor). Professor Adjunto IV do Curso de Graduação em Direito da Universidade Federal do Ceará (UFC). Diretor Acadêmico da Escola Superior de Advocacia da Ordem dos Advogados do Brasil, Seção Ceará (ESA - OAB/CE). Advogado 
Criminalista.

Fortaleza/CE.

E-mail:

nestoreasantiago@gmail.com

RESUMO: O trabalho visou a estudar a boa-fé objetiva (abuso do direito processual) no âmbito das colaborações premiadas por intermédio da análise do inteiro teor de decisões de órgãos colegiados do STF envolvendo as matérias publicadas entre 16/09/2013 (data de entrada em vigor da lei 12.850/2013) e 28/03/2018. Após a compilação e análise dos dados, observou-se que nenhum dos julgados abordou diretamente o abuso do direito processual apesar de se evidenciar, em diversos casos, possíveis manifestações desse fenômeno. Isso leva a questionar até que ponto os magistrados seriam capazes de observar, em suas demandas, a presença da boa-fé objetiva das partes.

PALAVRAS-CHAVE: Colaboração premiada; Delação premiada; Boa-fé objetiva; Abuso processual; Processo Penal.

ABSTRACT: The objective of this work was to study the objective good faith (abuse of procedural law) in the scope of the awarded collaborations by means of the analysis of the entire content of decisions of collegial organs of the STF involving the subject, published between 09/16/2013 (date of entry into force of Law 12.850 / 2013) and 03/28/2018. After compiling and analyzing the data, it was evidenced that in none of the judgments did it directly address the abuse of procedural law, despite, in several cases, evidence of possible manifestations of this phenomenon. This leads to questioning the extent to which magistrates observe in their demands the presence of the parties' objective good faith.

KEY WORDS: Collaboration award; Plea bargain; Good faith; Procedural abuse; Criminal procedure.

\section{INTRODUÇÃO}


A colaboração premial nunca esteve tão em discussão como nos últimos anos no cenário nacional. Vulgarmente confundida com a delação premiada, o instituto vem sendo utilizado pelos Ministérios Públicos (Federal e Estadual) e Polícia Civil para desbaratar esquemas de corrupção no âmbito administrativo, os quais outrora seriam difíceis de serem averiguados. Para tanto, o promotor (ou o delegado) faz um acordo com um dos acusados para que este, em troca de certos benefícios processuais (em geral redução de pena), delate os demais envolvidos no esquema, oferecendo provas da autoria e materialidade do delito praticado por cada um dos denunciados.

Todavia a colaboração premiada constitui num verdadeiro paradoxo ético. Busca-se com o auxílio do instituto promover a moralidade administrativa desvendando esquemas de corrupção, ao mesmo passo que se incentiva a traição dos envolvidos. Ademais, a ânsia por resultados pode levar a comportamentos processuais que constituem abuso de direito, tais como a chantagem feita por parte do Ministério Público (ou do delegado de polícia) para a formulação do acordo com o acusado ou, ainda, a formulação de delações caluniosas.

Como se percebe, apesar da atualidade do tema e de sua relevância social, poucos trabalhos discutem a relação entre a boa-fé objetiva (no caso abuso de direito processual) e o instituto da colaboração premiada.

Destarte, em face dessa bipolaridade da colaboração premiada aliada a pouca produção, abordando este viés, fez com que se buscasse, no presente estudo, não apenas sua relação macro com a boa-fé objetiva, mas, principalmente, buscou-se traçar e identificar formas de abuso processual na aplicação desse instituto.

Destaca-se que, ao se analisar a colaboração premiada sob a perspectiva do abuso processual, o estudo poderá dar nova perspectiva do tema. Explica-se: ou serão evidenciadas situações nas quais o abuso processual será flagrante nas colaborações premiadas, ensejando, na ocasião, uma maior reflexão sobre sua aplicação e sua validade no ordenamento constitucional; ou, em caso de ausência de situações que envolvam abusos processuais, gerará para o instituto um maior sentimento de segurança e ética na sua aplicação.

Sendo assim, este artigo busca estudar o instituto da colaboração premiada sob a óptica da boa-fé objetiva, na perspectiva da figura do abuso processual. Para tanto, 
analisará os contornos da boa-fé objetiva no ordenamento pátrio, dando relevo à questão da modalidade abuso de direito no Processo Penal; estudará o instituto da colaboração premiada no cenário nacional; e investigará, mediante a análise do inteiro teor de acórdãos do STF, envolvendo a figura da colaboração premiada, a questão do abuso de direito processual, apontando se, na fundamentação ou no dispositivo da decisão, há, de forma explícita, a manifestação do colegiado abordando a quebra da boa-fé objetiva na modalidade abuso de direito processual, elencando o tipo de abuso detectado.

Ressalta-se que a opção pela análise do inteiro teor das decisões, ao invés do estudo de todas as peças processuais das demandas compiladas (análise do caso concreto), deveuse por questões práticas. Em primeiro lugar, a análise da cadeia processual de cada uma dessas decisões (desde o juízo de primeiro grau até o STF ou de uma demanda original do próprio Supremo) geraria uma quantidade gigantesca de dados, que poderia levar a uma maior probabilidade de erro na análise dos dados.

Em segundo lugar, a pesquisa, ao avaliar a última decisão do órgão colegiado no caso compilado, busca retratar se a turma ou o plenário identificou situações caracterizadoras de abuso de direito processual. Portanto, não constitui escopo deste estudo apontar erros do colegiado quanto às tomadas de decisão no caso concreto, em especial a não observação da existência de abusos de direito presentes ao longo do processo.

Trata-se, destarte, de trabalho de natureza básica, de cunho qualitativo e quantitativo, com finalidade exploratória, mediante pesquisa bibliográfica (livros, revistas, teses, artigos científicos, dissertações, monografias etc.) e documental (legislação atinente ao tema e julgados do STF).

Quanto aos julgados, serão analisadas decisões colegiadas do STF do período compreendido entre 16/09/2013 (data de entrada em vigor da Lei 12.850/2013) e 28/03/2018, tendo as seguintes palavras-chave de busca: "colaboração adj premiada" ou “delação adj premiada”, em que, havendo mais de uma decisão relativa ao pleito, será computada a mais recente. Destaca-se que, apesar de entender que a delação premiada é uma das espécies de colaboração premiada trazidas no art.4º da Lei 12.850/2013, optou-se pelo uso das duas expressões: primeiro pelo fato de a delação estar contida no universo da colaboração; segundo, devido ao intuito de se aumentar a amostra; terceiro, para, em se 
considerando apenas o fator de busca "colaboração adj premiada" (gênero), deixar de analisar alguma amostra catalogada no STF apenas como delação premiada (espécie).

Sendo assim, após a compilação dos dados obtidos nas decisões coletadas, serão analisadas, em capítulo próprio, apenas aquelas que, em algum de seus componentes, envolverem aspectos relativos à boa-fé processual, em especial ao abuso de direito processual, classificando-as conforme o tipo de abuso identificado.

Para tanto, propõe-se a seguinte classificação das manifestações de abuso de direito processual: abuso na formulação do inquérito (AFI); abuso no direito de ação (ADA); abuso no direito de defesa (ADD); abuso no requerimento de medidas cautelares (AMC); abuso na instrução probatória (AIP); abuso no âmbito recursal (AAR); e abuso no exercício de ações autônomas (AAA).

Desse modo, o artigo foi dividido em três seções. A primeira dedica-se à questão da boa-fé objetiva e a sua relação com o abuso do direito, dando enfoque ao âmbito do Processo Penal. A segunda, por sua vez, traça um perfil do instituto da colaboração premiada, abordando seus requisitos, procedimentos e tipos de manifestações de abuso de direito. Na terceira seção, serão apresentadas decisões (colegiadas) do STF com a sua respectiva análise sob o prisma da boa-fé objetiva (abuso processual).

\section{A BOA-FÉ OBJETIVA E O ABUSO DO DIREITO PROCESSUAL}

A boa-fé objetiva, entendida como um dever de lealdade entre as partes envolvidas, constitui instituto originalmente desenvolvido para o Direito Civil, que aos poucos tivera sua aplicação expandida para os demais ramos do Direito. No âmbito processual, sua incorporação se deu com o novo Código de Processo Civil, Lei n ${ }^{\circ}$ 13.105/2015 (NCPC ${ }^{1}$ ), o qual, em seu art. $5^{\circ}$, aduz ser dever de qualquer pessoa, que participe do processo, agir de acordo com a boa-fé.

Voltado à efetivação de um processo colaborativo, o novo código tem, no instituto da boa-fé objetiva, um de seus alicerces para a concretização desse desiderato. De fato, não haveria como se pensar em colaboração processual se não houvesse por parte de todos os

\footnotetext{
${ }^{1}$ NEVES, Guilherme Pimenta da Veiga. Das normas fundamentais do Processo Civil: arts. $1^{\circ}$ a 12 . In: ALVIM, Angélica Arruda; ASSIS, Areken de; ALVIM, Eduardo Arruda; LEITE, George Salomão (Coord.). Comentários ao Código de Processo Civil. São Paulo: Saraiva, 2016. p. 59.
} 
agentes nele envolvidos uma atuação ética voltada para a solução da lide, gerando a tão sonhada pacificação social.

No âmbito processual, a quebra da boa-fé objetiva estaria relacionada à prática de um ato abusivo de direito ${ }^{2}$, ou seja, de um ato legalmente permitido, porém subjetivamente injusto $^{3}$ por extrapolar o dever de confiança. Para ser considerado como abusivo, o ato não necessariamente precisaria gerar dano material à parte adversa, podendo também ser caracterizado em situações em que haja apenas danos processuais como a preclusão ou a nulidade de um ato ${ }^{4}$.

Ressalta-se que o abuso somente seria evidenciado para aquelas situações em que a lei possibilita a discricionariedade de escolhas, todas lícitas e a parte age de forma distorcida ou desviando a finalidade legal ${ }^{5}$. De forma inversa, tendo a lei dado apenas uma única forma de conduta, não haveria como se falar em abuso, pois o agente não teria como fazer escolhas de qual ato praticar ou se desviaria ou distorceria a finalidade legal do mesmo.

Entretanto, deve-se ter bastante cuidado antes de taxar a conduta como abusiva, pois a discricionariedade de escolhas processuais pode gerar uma lícita não abusiva. Agir dentro desse dever de lealdade não é impedir que o advogado da parte adote a melhor estratégia processual para a obtenção do desiderato de seu cliente, mas que ambos busquem respeitar os demais envolvidos no processo, que evitem tumultuá-lo, objetivando a resolução definitiva do conflito. Desse modo, escolher qual tipo de prova utilizar ou recurso impetrar está dentro da margem de discricionariedade legal que o causídico possui, todavia, este somente estaria impedido de utilizá-los para tumultuar o processo ou procrastiná-lo.

\footnotetext{
${ }^{2}$ SOUZA, Alexander Araújo de. O abuso do Direito no Processo Penal. Rio de Janeiro: Lumen Juris, 2007a. p. 40-41.

${ }^{3}$ NASCIMENTO, Carlos Valder do. Abuso do exercício do direito: responsabilidade pessoal. 2.ed. São Paulo: Saraiva, 2015. p.71

${ }^{4}$ TARUFFO, Michele. Abuso de direitos processuais: padrões comparativos de lealdade processual (relatório geral). Revista de Processo, São Paulo, v. 177, a. 34, p. 153-183, jul. 2009.

${ }_{5}^{5}$ TARUFFO, Michele. Abuso del Processo. Revista de Processo Comparado, São Paulo, v. 5, p. 141-156, jan./jun. 2017.
} 
Portanto, a caracterização de uma conduta como abuso de direito é de extrema dificuldade na seara processual ${ }^{6}$. Isso se deve a três fatores: o primeiro está relacionado ao fato de qualquer ator processual (juiz, promotor, defensor, parte etc.) poder praticá-lo em qualquer de suas fases ${ }^{7}$; o segundo está na forma do ato processual praticado, o qual possui a aparência de lícito; por fim, não haver por parte dos órgãos julgadores o devido cuidado na apuração se o ato praticado quebrara ou não a boa-fé objetiva.

Destarte, a detecção do abuso do direito processual necessita da sensibilidade do juiz na análise do caso concreto ${ }^{8}$. Essa sensibilidade somente pode ser potencializada se houver nos juízos uma tradição de precedentes em que se aplique, no caso analisado, soluções obtidas de casos semelhantes ${ }^{9}$, bem como o treinamento adequado para a sua detecção.

No âmbito do processo penal, o Código de Processo Penal, decreto-lei $\mathrm{n}^{\circ}$ 3.689/1941 (CPP), não traz expressamente a figura do abuso de direito processual, apesar de abordar timidamente a figura da má-fé nos artigos 579 (fungibilidade recursal) e 653 (condenação do pagamento de custas para o autor que determinou a coação, quando o habeas corpus tenha sido julgado procedente $)^{10}$. Isso por si só não impossibilita a aplicação subsidiária do princípio da boa-fé objetiva em sua seara, apenas deve ser levado em conta que, por ser um sistema garantidor de liberdades, o dever de lealdade dos agentes processuais necessita ser analisado levando em conta princípios constitucionais da presunção do estado de inocência, da não autoincriminação, do juiz natural etc.

Uma vez partindo desta premissa, tem-se que, assim como no processo civil (e pelos mesmos motivos), a caracterização de condutas abusivas no processo penal é de difícil detecção e, muitas vezes, pode estar camuflada num suposto direito, garantia ou

\footnotetext{
${ }^{6}$ SENNA, Andressa Paula. O abuso de direito e a litigância de má-fé como impeditivos à marcha processual e ao resultado justo da prestação jurisdicional. Revista de Direito Privado, São Paulo, v. 40, p. 9-59, out./dez. 2009.

${ }^{7}$ SOUZA, Alexander Araújo de. O abuso do direito no requerimento de medidas cautelares típicas e atípicas no processo penal. Revista dos Tribunais, São Paulo, v. 856, p. 470-492, fev. 2007 b.

${ }^{8}$ TARUFFO, Michele. Abuso de direitos processuais: padrões comparativos de lealdade processual (relatório geral). Revista de Processo, São Paulo, v. 177, a. 34, p. 153-183, jul. 2009.

${ }^{9}$ ALVES, Fabio Wellington Ataíde. O abuso da garantia de defesa no processo penal: a renovação da defesa penal protelatória. Revista Direito e Liberdade, Mossoró, v. 7, n. 3, p. 83-100, jul. 2007.

${ }^{10}$ SOUZA, Alexander Araújo de. O abuso do Direito no Processo Penal. Rio de Janeiro: Lumen Juris, 2007a. p. 66.
} 
remédio constitucional ${ }^{11}$. Desse modo, o abuso de direito processual pode ocorrer em qualquer fase do processo e com qualquer dos agentes nele envolvido. No que concerne ao direito de ação, constitui prática abusiva a acusação, por parte do Ministério Público, sem o devido lastro de provas mínimas que liguem a autoria e a materialidade de um delito ao acusado ou a promoção de uma denúncia contendo mais fatos delitivos imputados ao acusado do que este realmente praticara.

Em relação ao direito de defesa, seria considerado abusivo quando um acusado: buscasse tumultuar o processo com a impetração de diversos recursos protelatórios; apresentasse provas falsas; inquerisse a oitiva de testemunhas desnecessárias para o caso. Mesmo nessas situações, por envolver direitos fundamentais, como o da presunção do estado de inocência e direito à não autoincriminação, haveria a necessidade de se analisar as circunstâncias do caso concreto para a evidenciação do abuso praticado.

Órgão julgadores, por sua vez, também estão sujeitos ao abuso de direito processual. Para tanto, basta se pensar no caso de se punir o acusado de forma injusta (seja por total dissonância com o conjunto probatório, seja por aplicar sanção superior ao de fato merecido). Há, de igual modo, a possibilidade de abuso ao não conceder liberdade provisória a um réu preso quando este tenha direito à mesma ou prendê-lo preventivamente quando outra medida distinta da prisão solucionasse o problema (v.g. uso de tornozeleira eletrônica nos casos de risco de fuga).

Desse modo, sendo possível a prática de abuso de direito na esfera penal em todos os momentos processuais e por qualquer dos envolvidos no processo, infere-se como se daria esse abuso no âmbito da colaboração premiada. Esse será o objeto do próximo tópico.

\section{COLABORAÇÃO PREMIADA}

Como visto no tópico anterior, o abuso de direito processual pode ocorrer em qualquer fase do processo e praticada por qualquer agente que nele se envolva. Tal fato não seria diferente na colaboração premiada. Desse modo, para evidenciar os diversos pontos da delação premiada capazes de serem objetos de abuso, faz-se necessário o entendimento do instituto, de seus requisitos e procedimento, o que se fará a seguir.

11 TARUFFO, Michele. Abuso de direitos processuais: padrões comparativos de lealdade processual (relatório geral). Revista de Processo, São Paulo, v. 177, a. 34, p. 153-183, jul. 2009. 
A colaboração premiada consiste em um instituto de política criminal auxiliar do Estado no combate à criminalidade, a partir da qual se busca do investigado, acusado ou condenado informações para a constituição de provas em troca de benefícios relativos à sanção, que deverá ser aplicada ao colaborador em seus próprios delitos ${ }^{12}$. No Brasil, a implementação desse instituto se deu de forma gradual, sendo um dos reflexos da chamada justiça criminal consensual, culminando com a promulgação da Lei 12.850/2013 na qual a colaboração premiada obtivera seus moldes atuais (art. $4^{\circ}$ ).

Segundo a referida lei, a colaboração premiada constitui um gênero, sendo a delação premiada (inciso I) uma de suas espécies. São outras formas de colaboração premiada: a revelação da estrutura hierárquica e divisão de tarefas da organização criminosa (inciso II); a prevenção de infrações penais decorrentes de atividades dessas organizações (inciso III); a recuperação (total ou parcial) do produto ou dos proveitos das infrações penais que essas organizações realizaram (inciso IV); e a localização de vítima com a eventual preservação da sua integridade física (inciso V).

Constitui a colaboração premiada um negócio jurídico, o qual, ao mesmo tempo, é um veículo de produção de provas (visto que a partir de suas informações são instauradas diligências na busca de carrear outras provas que endossem o que fora ali afirmado) e um meio de prova (quando considerado o depoimento em si) ${ }^{13}$. Sendo assim, a produção de um ato de abuso de direito processual pode ocorrer tanto na confecção dessa prova quanto na sua utilização. Desse modo, para se detectar possíveis abusos na colaboração premiada, faz-se necessário identificar os requisitos de validade desse instituto ${ }^{14}$ e o seu procedimento.

12 FREIRE JÚNIOR, Américo Bedê; DEZAN, Willy Potrich da Silva. Delação premiada e direitos fundamentais do sujeito passivo da persecução penal a partir da regulamentação constante na lei 12.850/2013. Revista eletrônica de Direito Processual, Rio de Janeiro, ano 11, v.18, n.1, p. 45, jan./abr. 2017.

${ }^{13}$ SANTOS, Marcos Paulo Dutra. Colaboração (delação) premiada. $2^{a}$ ed. Salvador: JusPodivm, 2017a. p. 85 .

${ }^{14} \mathrm{O}$ art. $4^{\circ}$ da lei $12.850 / 2013$ traz como requisitos da colaboração premiada a legalidade e a voluntariedade do colaborador, atrelados a um ou mais dos seguintes resultados: identificação dos demais coautores e/ou partícipes da organização criminosa com a respectiva individualização das infrações penais por eles praticados; revelação da estrutura hierárquica e da divisão de tarefas da organização; prevenção de infrações penais advindas das atividades da organização; recuperação total ou parcial do produto ou do proveito das infrações penais praticadas pela organização; e a localização de possíveis vítimas da organização com suas integridades físicas preservadas. 
Ministro Dias Toffoli, no julgamento do HC 127483/PR, apresentou dois requisitos de validade da delação premiada. O primeiro é ligado à declaração de vontade do colaborador, a qual deve ser livre, leal, consciente ${ }^{15}$ e ausente de má-fé (aqui tido como acusações inverídicas). O segundo requisito consiste em ser o objeto lícito, possível e determinado (ou determinável).

Sendo assim, toda a manifestação de vontade do delator deverá ser voluntária, sem pressões, sob pena de nulidade do ato. Destaca-se que voluntariedade difere de espontaneidade. Aquela requer uma vontade livre e consciente do colaborador, isenta de qualquer tipo de pressão, seja direta ou indireta ${ }^{16}$. Por sua vez, a espontaneidade infere que a atitude parta do próprio agente. Logo, poderá haver vontades espontâneas e vontades induzidas (sugeridas, não coagidas).

Partindo-se dessa premissa, poderá o MP ou o delegado de polícia propor acordos de delação premiada desde que o delator não se sinta coagido à prática do ato. A coação por parte da autoridade além de gerar a nulidade da peça colhida constitui um abuso (não apenas processual, mas de poder).

Ainda sobre a questão da coação, indaga-se sobre a figura do preso e a validade de suas delações. No que concerne à compatibilidade entre o consentimento do preso em fazer delação premiada e a prisão cautelar, sustentam Suxberger e Mello ${ }^{17}$ que o simples fato do réu estar cautelarmente preso, desde que a prisão se dê de forma legal, não é suficiente para configurar coação. Para tanto, aduzem que as coações, tanto no âmbito civil (arts. 151 e 153 do Código Civil - Lei ${ }^{\circ}$ 10.406/2002), quanto as descritas na esfera penal (crimes de constrangimento ilegal e ameaça - artigos 146 e 147 do Código Penal - Decreto-lei $\mathrm{n}^{\circ}$ 2.848/1940), exigem que o ato ensejador da coação seja ilegal. Desse modo, sendo a prisão legal não haveria coação do detento ${ }^{18}$.

\footnotetext{
${ }^{15}$ Resultante de um processo volitivo do acusado (independentemente de seu objetivo), com plena e total consciência da realidade.

${ }^{16}$ FREIRE JÚNIOR, Américo Bedê; DEZAN, Willy Potrich da Silva. Delação premiada e direitos fundamentais do sujeito passivo da persecução penal a partir da regulamentação constante na lei 12.850/2013. Revista eletrônica de Direito Processual, Rio de Janeiro, ano 11, v.18, n.1, p. 46, jan./abr. 2017.

${ }^{17}$ SUXBERGER, Antônio Henrique Graciano; MELLO, Gabriela Starling Jorge Vieira de. A voluntariedade da colaboração premiada e sua relação com a prisão processual do colaborador. Revista brasileira de Direito Processual Penal, Porto Alegre, v. 3, n. 1, p. 206-215, jan./abr. 2017. Disponível em: <http://www.ibraspp.com.br/revista/index.php/RBDPP/article/view/40/57>. Acesso em: 02 out. 2017.

${ }^{18}$ SANTOS, Marcos Paulo Dutra. Colaboração (delação) premiada. $2^{a}$ ed. Salvador: JusPodivm, 2017a. p. 147-148.
} 
Todavia, esquecem os autores, nessa ocasião, de analisar as características pessoais do delator. Mesmo constituindo uma prisão legal, haverá ocasiões em que este se sinta pressionado psicologicamente com o ambiente prisional. Tal fato implicaria uma coação silenciosa para o aceite do acordo de delação. A formulação e/ou a homologação de acordo de delação nessas circunstâncias pode se configurar um abuso na medida que a vontade do delator não seria mais livre.

Suxberger e Mello ${ }^{19}$ ainda trazem outros quatro fatores que afastariam o risco de coação. O primeiro deles, conforme art. $4^{\circ}, \S 15$ da Lei 12.850/2013, consiste em ser toda a negociação da delação acompanhada pelo advogado do delator, o qual, ao perceber sinais de coação, adotaria medidas para a sua cessação. Todavia, advogados de defesa inexperientes e/ou relapsos fragilizariam tal garantia legal, podendo não constatar a coação ou pior, não a combater, tornando os acordos feitos neste cenário nulos em face do abuso praticado pelo proponente da delação.

O segundo fator está na obrigatoriedade de o juiz homologar o acordo de delação. Nessa ocasião, o magistrado analisaria a presença dos seus requisitos legais, podendo, em face do art. $4^{\circ}, \S 7^{\circ}$ da Lei $12.850 / 2013$, promover a oitiva sigilosa do colaborador e de seu causídico $^{20}$. Porém, a depender da personalidade do juiz ou das pressões sociais do caso, a coação poderia ser propositalmente não apreciada pelo magistrado, constituindo uma forma de abuso de direito do judiciário.

O terceiro fator estaria relacionado à possibilidade de gravações da delação e seu posterior controle. Previu o art. $4^{\circ}, \S 13$ da lei de organizações criminosas que, sempre quando possível, os atos de colaboração seriam registrados por meio de gravações capazes de obter a maior fidelidade possível das informações prestadas pelo delator ${ }^{21}$. Entretanto, a utilização de delações realizadas sem a devida gravação ou com a produção da mesma com cortes em momentos que se relate algum fato importante pode constituir abuso de direito.

Por fim, o último fator relacionado ao impedimento de coação estaria na proteção física do delator. $\mathrm{O}$ art. $5^{\circ}$ do referido diploma legal assegura ao mesmo o direito a sua integridade física, o que, por si, afastaria qualquer tipo de coação que afetasse tal

\footnotetext{
${ }^{19}$ SUXBERGER, Antônio Henrique Graciano; MELLO, Gabriela Starling Jorge Vieira de. Op. cit. p. 206215.

${ }^{20}$ Ibidem. p. 207-208.

${ }^{21}$ Ibidem. p. 209.
} 
incolumidade $^{22}$. Porém nada impede que este tenha uma ameaça velada por parte das autoridades, ou que estas, por exemplo, neguem itens indispensáveis, tais como comida ou água no intuito de pressionar o acordo de delação. Logo, a prática de tortura para a obtenção da delação, bem como a sua não apuração, além de delito próprio, constituem um abuso de direito processual.

Quanto ao depoimento do delator, tem-se que as mentiras por este relatadas consubstanciariam abuso de direito. Nesse sentido, a própria Lei $\mathrm{n}^{\mathrm{o}} 12.850 / 2013$, no seu art. 19, aponta constituir crime a falsa imputação de delito pelo colaborador a outrem, sendo, portanto, a mentira praticada por este um comportamento reprovável (art. $4^{\circ}, \S 1^{\circ}$ ). Ademais, o referido diploma legal disciplina como uma obrigação do mesmo dizer a verdade (art. $\left.4^{\circ}, \S 14\right)$.

Todavia, no julgamento do HC 127483/PR ${ }^{23}$, o min. Dias Toffoli indica ser irrelevante a questão do delator faltar com a verdade nesta ou em delação anterior, haja vista que os efeitos do acordo firmado somente serão revisados e concedidos (ou não) no momento do julgamento, em que um dos fatores de análise é a personalidade do delator. Apesar da suposta irrelevância, como no momento do julgamento há por parte do juiz a análise da veracidade do depoimento apresentado pelo delator para a concessão dos benefícios acordados, entende-se que a mentira é, em si, relevante e passível de punição. Ademais, ao mentir, o colaborador poderá envolver terceiros acusados injustamente, prejudicando suas vidas e reputação.

No que concerne à competência para pactuar delações premiadas, dispõe a Lei $\mathrm{n}^{\circ}$ 12.850/2013 que o acordo de colaboração premiada pode ser firmado nos inquéritos policiais entre o delegado de polícia e o investigado, com manifestação do Ministério Público, e, a qualquer tempo processual, entre o réu e o Ministério Público (art. $4^{\circ}, \S 6^{\circ}$ ), em ambos os casos o delator deverá ser assistido por seu defensor em todas as fases da negociação, confirmação e execução da colaboração (art. $\left.4^{\circ}, \S 11\right)^{24}$.

\footnotetext{
${ }^{22}$ Ibidem. p. 209.

${ }^{23}$ BRASIL. Supremo Tribunal Federal. Habeas Corpus n $\mathbf{n}^{\mathbf{0}}$ 127.483/PR. Relator: Min. Dias Toffoli. Brasília, DF, 27 de agosto de 2015. Disponível em: <http://www.stf.jus.br/portal/processo/verProcessoPeca.asp?id $=308597935 \&$ tipoApp=.pdf $>$. Acesso em: 16 nov. 2017 .

${ }^{24}$ Santos aponta ser viável a colaboração unilateral do acusado, sem a necessidade de um acordo prévio com o Ministério Público ou com o Delegado. Cf. SANTOS, Marcos Paulo Dutra. Colaboração unilateral premiada como consectário lógico das balizas constitucionais do devido processo legal brasileiro. Revista
} 
Destaca-se que, segundo o referido art. $4^{\circ}, \S 6^{\circ}$, o juiz não participa da negociação, tomando contato de sua existência no momento da requisição (acordos processuais ou préprocessuais realizados diretamente pelo MP) ou representação (quando realizado por delegado de polícia) do acordo para homologação. Nesse momento, o magistrado se restringe a analisar a regularidade, a legalidade e voluntariedade do acordo, podendo, antes da homologação, ouvir sigilosamente o colaborador na presença de seu advogado (art. $4^{\circ}$, $\left.\S 7^{\circ}\right)$, sem analisar o mérito de seu conteúdo.

Salienta-se que poderá o juiz, na apreciação do acordo firmado, recusar sua homologação (quando não estiverem presentes os requisitos legais) ou adequá-lo ao caso concreto $\left(\operatorname{art} .4^{\circ}, \S 8^{\circ}\right)$. Qualquer homologação realizada pelo magistrado sem a averiguação dos requisitos legais ou de sua adequação ao caso concreto pode caracterizar abuso de direito processual. Desse modo, a fundamentação dada pelo juízo na homologação do acordo é de extrema importância para a averiguação dessa conduta.

Destaca-se que o colaborador, durante a instrução da sua colaboração, pode não cumprir o acordado ou fazê-lo de forma parcial, podendo inclusive retratar-se da proposta, fato que ensejará a não utilização de forma exclusiva das provas autoincriminadoras trazidas pelo delator para a sua condenação (art. $4^{\circ}, \S 10$ da Lei $\left.12.850 / 2013\right)^{25}$. Nessas circunstâncias, a utilização dessas provas por parte do MP ou sua apreciação pelo magistrado para a condenação do delator constituiriam abuso de direito processual por parte desses órgãos.

Destaca-se que o conteúdo do acordo de colaboração premiada passa a ser público no momento do oferecimento da denúncia pelo Ministério Público (art. $7^{\circ}$, $\S 3^{\circ}$ da Lei 12.850/2103), excetuando-se os direitos de sua proteção como testemunha e de ter sua identidade/imagem divulgada pelos meios de comunicação (art. $5^{\circ}$, I e V do referido diploma legal). A divulgação do conteúdo de acordo anterior ao recebimento da denúncia constitui abuso de direito processual do responsável por induzir a opinião pública, gerando pressão popular e ferindo o direito constitucional da presunção do estado de inocência dos acusados.

brasileira de Direito Processual Penal, Porto Alegre, v. 3, n. 1, p. 152-160, jan./abr. 2017b. Disponível em: <http://www.ibraspp.com.br/revista/index.php/RBDPP/article/view/49/55>. Acesso em: 02 out. 2017.

${ }^{25}$ Conforme o referido parágrafo, o Ministério Público possui igual direito à retratação do acordo. 
Outro ponto capaz de constituir abuso de direito processual é a questão da escolha de benefícios a serem negociados pelo Ministério Público ou pelo Delegado de Polícia. Segundo Silva, a falta de critério do Ministério Público para a formulação das cláusulas do acordo e da sua avaliação no momento da sentença constituem uma afronta ao sistema dosimétrico brasileiro ${ }^{26}$.

Por sua vez, Jardim entende que, nos casos em que haja mais de um colaborador delatando uma organização criminosas, por não haver critérios objetivos para a escolha desta ou daquela benesse, pode-se gerar tratamento não isonômicos ${ }^{27}$. Basta se imaginar dois colaboradores que obtiveram benefícios distintos (v.g. ausência de condenação e redução da pena), cujas delações, todavia, tivessem efeitos similares na condenação de um grupo criminoso. Nessas circunstâncias, tais tratamentos seriam considerados abusivos por lhes faltar isonomia.

No que concerne ao valor probatório da colaboração premiada, dispõe o art. $4^{\circ}, \S 16$ da Lei 12.850/2013 que nenhuma sentença condenatória poderá se basear apenas nas declarações dadas pelo colaborador. Em face dessa situação, Bittar afirma que a condenação dos delatados necessita a obtenção de provas capazes de corroborar com as alegações prestadas pelo colaborador ${ }^{28}$, pois sentenças condenatórias baseadas apenas nas declarações do colaborador constituem abuso por parte do magistrado.

No caso de a colaboração ter sido realizada no momento da execução da pena, poderá o condenado tê-la reduzido até a metade ou progredir de regime, mesmo que sejam ausentes os requisitos objetivos para tal $\left(\operatorname{art.} 4^{\circ}, \S 5^{\circ}\right)$. A não apreciação pelo magistrado desses benefícios, a não concessão ou a concessão a menor pode constituir abuso por parte do juiz.

Como se infere, durante todo o procedimento da delação premiada (formulação, negociação, homologação, apreciação do mérito e concessão de benefícios), é possível a

\footnotetext{
${ }^{26}$ SILVA, Marcelo R. A colaboração premiada como terceira via do direito penal no enfrentamento à corrupção administrativa organizada, Revista brasileira de Direito Processual Penal, Porto Alegre, v.3, n.1, p. 306, jan./abr. 2017.

27 JARDIM, Afrânio Silva. A influência norte-americana nos sistemas processuais penais latinos. Revista eletrônica de direito processual. Rio de Janeiro. Ano 10, v.17, n.2, jul./dez. 2016. p. 07. Disponível em: <http://www.e-publicacoes.uerj.br/index.php/redp/article/view/26598/18956>. Acesso em: 25 jul. 2018.

${ }^{28}$ BITTAR, Walter Barbosa. O problema do conteúdo da valoração do depoimento dos delatores diante do conceito da justa causa para o regular exercício da ação penal. Revista Brasileira de Direito Processual Penal, Porto Alegre, v. 1, n. 3, p.245, jan.-abr.2017.
} 
prática de atos abusivos por parte dos atores processuais envolvidos. Entretanto, como visto, a sua evidenciação no caso concreto é de extrema dificuldade, sendo a tarefa facilitada se os órgãos julgadores tivessem uma cultura de precedentes de casos similares. Uma vez ciente dessa perspectiva, resta analisar como o colegiado do STF em demandas envolvendo colaborações premiadas trataram a questão do abuso do direito processual.

\section{ANÁLISE DAS DECISÕES DO STF}

Tendo como base de pesquisa as palavras "delação" ADJ "premiada", observou-se a existência de 41 decisões colegiadas do STF, das quais apenas 22 estão compreendidas dentro do período objeto de análise deste artigo (16/09/2013 a 28/03/2018).

Utilizando-se como parâmetro de pesquisas as palavras "colaboração" ADJ "premiada", obteve-se o número de 44 processos, todos dentro do período de compilação do estudo. Ocorre que, dos 44 processos encontrados nessa base de dados, averiguou-se que 8 destes também constavam na pesquisa "delação" ADJ "premiada".

Sendo assim, dos 66 resultados encontrados, retirando-se os processos coincidentes, finalizou-se com a presença de 58. Destes, por sua vez, 07 (Inq 4130 QO, HC 117946, AP 477 AgR, AP 694, Inq 4146, Rcl 21258 AgR e AC 3872 AgR) tramitavam em segredo de justiça, fato que impossibilitou a análise do inteiro teor das decisões neles contidas.

Destaca-se, nesse ponto, que no Inquérito 3990 foram analisadas 04 decisões colegiadas (embargos de declaração) - 03 oriundos de corréus e 01 do MP.

Na pesquisa, inferiu-se que a Pet 6138 AgR apareceu duas vezes com as seguintes denominações: "Pet 6138 AgR" e "Pet 6138 AgR-segundo". Caso semelhante aconteceu no Inq 3984, em que havia dois embargos de declaração, um para cada corréu (Inq 3984 e Inq 3984ED). Tendo em vista que tal divisão remetia a duas decisões de corréus distintos, manteve-se a contagem como decisões autônomas para efeitos de análise de dados.

Sendo assim, das 54 decisões ${ }^{29}$ que houve acesso ao seu inteiro teor, constatou-se que em nenhuma delas havia indicação explicita de abuso do direito processual. Porém, analisando, nestas decisões, as condutas que poderiam ser caracterizadas como

\footnotetext{
${ }^{29}$ Total de decisões $(54)=$ processos Compilados $(66)$ - ações duplicadas $(8)$ - ações em segredo de justiça (7) + embargos de declaração extras do Inq 3390 (3)
} 
manifestações de abuso processual, o quadro muda de figura, constatando-se 21 delas com indícios de abuso (vide Tabela 1 e gráficos 1 a 3).

Desse modo, analisando as 21 decisões que contêm alguma possível manifestação de abuso de direito processual, inferiu-se 04 tipos de abusos assim elencados: 04 abusos do direito de ação (ADA); 01 abuso do direito de defesa (ADD); 12 abusos no âmbito recursal (AAR); e 05 abusos no exercício de ações autônomas (AAA), não se evidenciando outras espécies de abusos ${ }^{30}$.

Destaca-se, no Inquérito 3204, que a decisão continha um possível abuso do direito de ação (ausência de justa causa da participação de corréu na denúncia) e um abuso no direito de defesa (corréu que se ocultava para não ser citado e pleiteava a sua nulidade).

Conforme o art. 41 do CPP, a denúncia deve conter a exposição do fato criminoso com todas as circunstâncias que o envolvem, bem como a individualização das condutas praticadas por cada agente acusado, não sendo necessária a comprovação definitiva da ação/omissão, bastando haver um conjunto probatório mínimo que aponte indícios de autoria e materialidade. O Ministério Público pode agir com abuso de direito processual na versão direito de ação (ADA) quando, no intuito de elucidar um crime dando uma resposta à sociedade, promova uma ação penal contra um indivíduo sem lhe apontar sua participação específica no crime, trazendo provas mínimas desse envolvimento.

Tal situação foi observada nos Inquéritos no 3.204, 3.998 e 4112 e na questão de ordem ao inquérito $\mathrm{n}^{\mathrm{o}} 3.815$ em que os possíveis ADA estão vinculados à apresentação de denúncia sem o elemento comprobatório mínimo de participação dos acusados. No Inquérito $\mathrm{n}^{\mathrm{o}} 3.204$, por exemplo, a peça inicial foi recebida em parte, sendo rejeitada em relação ao acusado de iniciais R.S.M. por não ter o Ministério Público apresentado material probatório mínimo que comprovasse o envolvimento do acusado nem de como ocorrera a sua participação.

Por sua vez, no inquérito $\mathrm{n}^{\circ} 3.998$, a colaboração premiada que serviu de base para denúncia estava desprovida de outros meios probatórios mínimos suficientes para que houvesse o recebimento da peça processual e o início da demanda judicial. Já no Inquérito $\mathrm{n}^{\circ}$ 4.112, não foi apontado na denúncia como as provas advindas de uma colaboração

\footnotetext{
${ }^{30}$ Abuso na formulação de inquérito (AFI), abuso no requerimento de medidas cautelares (AMC) e abuso na instrução probatória (AIP).
} 
premiada vinculariam as corrés de inicias C.S.M.C.M. e L.G.L.R. aos crimes de lavagem de dinheiro, acarretando, em quanto a estas, o não recebimento da denúncia.

Por fim, na questão de ordem ao inquérito, evidenciou-se que a denúncia contra os corréus J.A. e R.G. tinha sido baseada em uma delação premiada sem o devido lastro probatório mínimo da materialidade do delito. Ademais, o relator do julgamento destaca trecho do delator no qual expressamente diz não possuir prova alguma contra os acusados.

Quanto ao inquérito $\mathrm{n}^{\mathrm{o}} 3.204$ também se evidenciou um abuso de direito de defesa (ADD) da acusada de iniciais S.D.C. a qual alegou a nulidade de sua notificação pessoal quando este dera causa à mesma em face de sua ocultação. Consoante observado no relatório do acórdão de recebimento da denúncia, por diversas vezes, o oficial de justiça buscara a notificação da acusada, mantendo contato nas diligências com a irmã da mesma para a citação por hora certa. Na ocasião, a irmã de S.D.C. informara que, mesmo ciente, a acusada não queria receber a notificação. Desse modo, não poderia a acusada, ciente do intuito do oficial em notificá-la, alegar em sua defesa a nulidade de citação que ela contribuíra para ocorrer.

No que concerne aos abusos de direito no âmbito recursal (AAR), constatou-se que buscavam discutir situações não condizentes com o intuito do recurso. Os inquéritos $\mathrm{n}^{\circ}$ 3.979, 3.983, 3.984, 3.990 (segundo, terceiro e quarto ${ }^{31}$ ), o inquérito $\mathrm{n}^{\mathrm{o}} 3.984 \mathrm{ED}^{32}$, o Agravo Regimental ao habeas corpus $\mathrm{n}^{\circ} 134.190$, o Recurso ordinário ao habeas corpus $\mathrm{n}^{\circ}$ 124.192 e o Agravo Regimental à Petição $n^{\circ}$ 6.840, todas as decisões analisadas desses processos foram embargos de declaração nos quais os embargantes visavam a discutir matéria fática não objetivando elucidar uma ambiguidade, obscuridade, contradição ou corrigir uma omissão tal como descrito no art. 620 do CPP.

À guisa de exemplo, no ED do AgR ao $\mathrm{HC} \mathrm{n}^{\circ} 134.190$, o embargante buscava rediscutir a efetividade de sua colaboração premiada para a elucidação do crime de lavagem de dinheiro. Na ocasião, quando da sua sentença, o juízo competente não havia levado em consideração a delação realizada pelo embargante por não ter sido esta suficiente para configurar a materialidade do crime aos envolvidos. Como se infere, não poderia em embargos de declaração rediscutir a apreciação do juízo que prolatou a

\footnotetext{
${ }^{31}$ Numeração em face de cada peça ter sido impetrada por um réu distinto.

${ }^{32}$ Inq. $\mathrm{N}^{\mathrm{o}} 3.984$ e $3.984 \mathrm{ED}$ possuem embargantes distintos.
} 
sentença por envolver a necessidade de análise das provas dos autos e não ser este o escopo desse tipo de recurso.

De igual forma, o Recurso Ordinário ao habeas corpus $\mathrm{n}^{\circ} 116.108$ visava a discutir matéria preclusa com trânsito em julgado, a qual deveria ser objeto de revisão criminal. Na ocasião, buscava o réu anular o julgamento do tribunal do júri que se baseou em material oriundo de delação premiada que supostamente não lhe fora dado direito de defesa, sendo, portanto, uma prova nula.

Todavia, segundo o art. 571, V do CPP, nulidades posteriores à pronúncia deveriam ter sido arguidas logo depois de anunciado o julgamento e apregoadas as partes. $\mathrm{O}$ fato não ocorrera e, após as decisões dos recursos especial e extraordinário, houve o trânsito em julgado do assunto. Tal circunstância ensejaria a promoção de uma ação de revisão criminal para se discutir a nulidade da prova que ensejou a condenação. Buscar, portanto, uma via recursal inapropriada pode configurar um abuso do direito processual do acusado, quando não há outro instrumento processual adequado e não haja dúvida objetiva sobre qual procedimento adotar.

Já o agravo regimental ao habeas corpus $\mathrm{n}^{\circ} 134.190$ buscava rediscutir o não reconhecimento do juízo ordinário da materialidade do crime de lavagem de dinheiro descrito na delação premiada do crime feita pelo agravante (e, por conseguinte, seus benefícios) que não fora apreciada pelo STJ em sede de habeas corpus por envolver análise de matéria fática. Como tal circunstância de igual forma não pode ser apreciada em sede recursal de $\mathrm{HC}$, o que pode ensejar a conclusão de que poderia ter havido abuso processual (AAR) neste caso específico.

Por fim, quanto ao abuso processual nas ações autônomas (AAA), evidenciou-se que nos habeas corpus $\mathrm{n}^{\mathrm{o}} 108.716^{33}, 109.043^{34}$ e $127.221^{35}$ os impetrantes buscavam rediscutir matérias fáticas, as quais não constituem objeto desta ação e, no caso dos habeas corpus $\mathrm{n}^{\mathrm{o}} 132.143^{36}$ e 133.600 , visavam a discutir decisão de relator de tribunal superior

\footnotetext{
${ }^{33}$ Buscava rediscutir a colaboração do impetrante e a aplicação da minorante do art. 14 da lei no 9.807/1999, necessitando a reapreciação das provas dos autos originais.

${ }^{34}$ Visava a rediscutir a aplicação das circunstâncias judiciais (elementos de convicção) descritas no art. 59 do $\mathrm{CP}$, que implica na reapreciação do conjunto probatório.

${ }^{35}$ Objetivava rediscutir a aplicação das circunstâncias judiciais (elementos de convicção) descritas no art. 59 do $\mathrm{CP}$, que implica na reapreciação do conjunto probatório.

${ }^{36}$ Destaca-se, entretanto, que o relator, mesmo não conhecendo o writ, concedera a liberdade de ofício do paciente. $\mathrm{O}$ impetrante foi preso preventivamente enquanto governador, sob argumento de continuar
} 
que indeferiu liminar de $\mathrm{HC}$, desafiando o entendimento súmula 691 do $\mathrm{STF}$, o que também contraria o objetivo do writ.

Finalmente, se filtrarmos os julgamentos em que a discussão sobre a colaboração premiada se dá de forma principal (quanto a sua validade, sua publicidade, seu acesso ou efeitos da pena) tem-se uma significativa redução dos valores obtidos.

Conforme o gráfico 4, das 21 decisões que possuíam algum tipo de abuso envolvendo colaborações premiadas, evidenciou-se que, em apenas 05 delas, o abuso estaria ligado à própria colaboração. São estes: os inquéritos 3.998 e 4.112, o embargo de declaração no Agravo Regimental ao habeas corpus 134.190 e a Questão de Ordem ao Inquérito 3.815 .

Esse número reduzido de abusos de direito processual na própria colaboração premiada não indica que, na prática, não haja tais violações da boa-fé objetiva. Como visto, a observação do abuso de direito é de difícil constatação e poderia configurar o primeiro fator de uma amostra tão baixa.

Outro fator a ser considerado é que a maioria das demandas analisadas impossibilitavam a análise do conjunto probatório, dentre eles as colaborações premiadas. O supremo, ao não analisar o teor e os requisitos dessas provas, impede a coleta de dados de forma mais precisa sobre a ocorrência ou não de abusos de direito na delação premiada, devendo-se, em pesquisas futuras, analisar como os tribunais inferiores ou, até mesmo, os juízes de primeiro grau de uma determinada região estão observando a questão da boa-fé objetiva nas colaborações premiadas por eles apreciadas.

\section{CONCLUSÕES}

Analisando os dados oriundos da seção anterior, inferiu-se que pouco se rotula um ato praticado no processo como abuso de direito processual. Isso se dá em parte pelo fato de não ser um costume associar tal prática como abuso ou ser sua detecção difícil, principalmente se levar em consideração aspectos subjetivos para a sua caracterização.

exercendo a influência do cargo para obstar o processo. Todavia, no momento da apreciação do writ pelo $\mathrm{STF}$, o mandado do impetrante já havia se encerrado há quase um ano, fato este que fez o tribunal concluir que se esvaiu as razões da prisão preventiva e a concessão de ofício do mandado de soltura. 
No que concerne às demandas envolvendo colaboração premiada, alguns pontos merecem destaques. O primeiro deles é o próprio sistema de busca do STF, o qual, entendendo ser sinônimos os termos "delação" e "colaboração", deveria apresentar idênticos resultados. Em sentido inverso, não poderia apresentar resultados coincidentes no caso de considerá-los institutos distintos. Ademais, poderia existir no sistema um filtro determinando se a base procurada constitui objeto principal do julgado ou aparece de maneira incidental.

Evidencia-se na pesquisa realizada o grande número de agravos regimentais e embargos de declaração, em que, em relação aos últimos, apenas 01 dos 11 julgados analisados não visava a discutir fatos e matérias já debatidos no julgamento atacado. Esse fato pode ser caracterizado como abusivo desde que não seja uma manobra de préquestionamento para possível recurso extraordinário ou no caso de haver de fato uma dúvida quanto à decisão atacada (obscuridade, contradição e omissão). Entretanto, excetuando os casos extremos, o limiar entre o abuso e o efetivo direito pode ser de difícil constatação.

No tocante aos processos de colaboração premiada, alguns temas, a depender do caso concreto, podem configurar abuso de direito processual. Destarte, é passível de ser detectável abusos oriundos da parte acusadora, do delator e, até mesmo, da parte julgadora.

Quanto aos abusos relativos à parte acusadora, pode-se inicialmente destacar o uso das prisões como fator de coação do acusado para que este acorde uma delação premiada. Nesse caso, compete ao juízo competente, em primeiro lugar, analisar a necessidade da prisão cautelar, haja vista ela configurar a última medida a ser adotada. Ademais, deve o magistrado estar atento ao excesso de prazo das prisões cautelares em curso para, de igual forma, evitar qualquer coação psicológica capaz de ensejar o acusado a solicitar uma delação (não pode o Estado utilizar de sua própria torpeza para alcançar seus objetivos cabe sim melhorar seu aparelhamento e investir em serviço de inteligência).

Outro mecanismo utilizado para pressionar o acusado a promover a colaboração premiada é a denúncia sem a devida instrução de evidências capazes de caracterizar um indício mínimo de o acusado ter cometido o fato delitivo ou imputar um crime mais grave do que praticara o indiciado. A depender do caso concreto, tal procedimento poderá configurar uma forma abusiva do direito de ação. 
Quanto ao acusado, este comete abuso ao firmar o acordo de delação e delatar situações inverídicas ou informações parciais. Apesar da doutrina e da jurisprudência relativizarem a questão da delação inverídica e a parcial - haja vista a análise que o magistrado fará do conteúdo, eficácia e efetiva colaboração do delator no momento da sentença -, tais comportamentos constituem má-fé, pois o art. $4^{\circ}, \S 14$ da Lei 12.850/2013 atrela a delação premiada ao compromisso de se dizer a verdade, e o art. $4^{\circ}, \S 10$, do mesmo diploma legal, dá a possibilidade de retratar da delação realizada.

Também constitui um ato de abuso, a depender da situação fática, acusar falsamente pessoas que sabidamente não cometeram delito e não pertençam à organização criminosa. Tal situação constitui algo tão deplorável que a própria lei das organizações criminosas a caracterizou como um delito (art. 19).

Há também de se considerar abusiva a possibilidade de ambas as partes se utilizarem de recursos de forma protelatória ou, até mesmo, para rediscutir matéria fática quando processualmente não for mais possível.

Quanto aos magistrados, vê-se principalmente a questão da desídia processual, analisando os fatos apresentados de forma displicente ou simplesmente demorando acima do justificável a analisar os pedidos realizados - afetando a celeridade processual e causando impactos negativos à vida do acusado, principalmente se este estiver preso. Ademais, o magistrado deve estar sempre atento para poder diferenciar, no caso concreto, quando uma ação constitui uma manobra processual, legalmente lícita e dentro dos limites da boa-fé de um ato de abuso, o qual deverá ser reprimido dentro dos limites legais.

Ademais, como destacado, apesar da constatação nos julgados do STF, ora analisados de um baixo número de colaborações premiadas, cujo teor constitua o objeto principal de abuso processual, isso não implica necessariamente que não há abusos nesses meios de prova. O abuso pode ocorrer nas instâncias inferiores em que tais peças são produzidas e avaliadas, todavia, como a maioria dos julgados do colegiado do supremo não possibilitam o reexame de conteúdo probatório, os números encontrados podem estar subestimados, abrindo o ensejo que novas pesquisas sejam realizadas nas próprias turmas do STF ou em tribunais estaduais e federais.

Como visto, muito tem a ser discutido sobre o tema. $\mathrm{O}$ abuso processual é uma realidade que os operadores do Direito não podem fechar os olhos. Ele pode estar presente 
em qualquer procedimento judicial, sendo a colaboração premiada um ambiente fértil para sua aparição.

\section{REFERÊNCIAS}

ALVES, Fabio Wellington Ataíde. O abuso da garantia de defesa no processo penal: a renovação da defesa penal protelatória. Revista Direito e Liberdade, Mossoró, v. 7, n. 3, p. 83-100, jul. 2007.

BITTAR, Walter Barbosa. O problema do conteúdo da valoração do depoimento dos delatores diante do conceito da justa causa para o regular exercício da ação penal. Revista Brasileira de Direito Processual Penal, Porto Alegre, v. 1, n. 3, p.225-251, jan.-abr.2017. BRASIL. Planalto. Decreto-lei no 2.848, de 07 de dezembro de 1940. Código Penal. Disponível em <http://www.planalto.gov.br/ccivil_03/decreto-lei/Del2848compilado.htm> Acesso em: 19 ago. 2017.

Decreto-lei $\mathrm{n}^{\mathrm{o}} 3.689$, de 03 de outubro de 1941. Código de Processo

Penal. Disponível em <http://www.planalto.gov.br/ccivil_03/decreto-lei/Del3689.htm>. Acesso em: 19 ago. 2017.

Lei n ${ }^{\circ}$ 5.869, de 11 de janeiro de 1973. Código de Processo Civil. Disponível em <http://www.planalto.gov.br/ccivil_03/leis/L5869.htm>. Acesso em: 19 ago. 2017.

Lei $\mathrm{n}^{\circ}$ 9.807, de 13 de julho de 1999. Estabelece normas para a organização e a manutenção de programas especiais de proteção a vítimas e a testemunhas ameaçadas, institui o Programa Federal de Assistência a Vítimas e a Testemunhas Ameaçadas e dispõe sobre a proteção de acusados ou condenados que tenham voluntariamente prestado efetiva colaboração à investigação policial e ao processo criminal. Disponível em <http://www.planalto.gov.br/ccivil_03/leis/L9807.htm> Acesso em: 25 nov. 2017.

Lei $\mathrm{n}^{\circ}$ 12.850, de 02 de agosto de 2013. Define organização criminosa e dispõe sobre a investigação criminal, os meios de obtenção da prova, infrações penais correlatas e o procedimento criminal; altera o Decreto-Lei no 2.848, de 7 de dezembro de 1940 (Código Penal); revoga a Lei $\mathbf{n}^{\circ}$ 9.034, de 3 de maio de 
1995; e dá outras providências. Disponível em: <http://www.planalto.gov.br/ccivil_03/_ ato2011-2014/2013/lei/112850.htm>. Acesso em: 19 ago. 2017. Lei $\mathrm{n}^{\mathrm{o}}$ 13.105, de 16 de março de 2015. Código de Processo Civil.

Disponível em $\quad<\quad$ http://www.planalto.gov.br/ccivil_03/_ato20152018/2015/lei/113105.htm>. Acesso em: 19 ago. 2017. Supremo Tribunal Federal. Recurso Ordinário no Habeas Corpus no

116.108/RJ. Relator: Min. Ricardo Lewandowski. Brasília, DF, 01 de outubro de 2013. Disponível em: $<$ http://www.stf.jus.br/portal/processo/verProcessoPeca.asp?id=176828731\&tipoApp=.pdf >. Acesso em: 16 nov. 2017.

\section{Recurso Ordinário no Habeas Corpus $\mathbf{n}^{0}$}

133.600/RJ. Relator: Min. Ricardo Lewandowski. Brasília, DF, 01 de outubro de 2013. Disponível em: <http://www.stf.jus.br/portal/processo/verProcessoPeca.asp?id=312349248\&tipoApp;=.pdf >. Acesso em: 16 nov. 2017.

Habeas Corpus $\mathbf{n}^{\mathbf{0}}$ 108.716/SP. Relator: Min. Teori

Zavascki. Brasília, DF, 05 de novembro de 2013. Disponível em: $<$ http://www.stf.jus.br/portal/processo/verProcessoPeca.asp?id=185143893\&tipoApp=.pdf >. Acesso em: 16 nov. 2017.

Ação Penal no 477/SP. Relator: Min. Edson Fachin, DF, 08 de novembro de 2013. Disponível em: $<$ http://www.stf.jus.br/portal/processo/verProcessoAndamento.asp?numero=477\&classe= AP-AgR\&codigoClasse $=0 \&$ origem $=\mathrm{JUR} \&$ recurso $=0 \&$ tipoJulgamento $=\mathrm{M}>$. Acesso em: 16 nov. 2017.

Habeas Corpus no 118.578/PE. Relator: Min. Dias Toffoli. Brasília, DF, 03 de dezembro de 2013. Disponível em: $<$ http://www.stf.jus.br/portal/processo/verProcessoPeca.asp?id=200645739\&tipoApp=.pdf >. Acesso em: 16 nov. 2017.

Habeas Corpus $\mathbf{n}^{\mathbf{0}}$ 109.043/SP. Relator: Min. Teori Zavascki. Brasília, DF, 10 de dezembro de 2013. Disponível em: 
<http://www.stf.jus.br/portal/processo/verProcessoPeca.asp?id=202603035\&tipoApp=.pdf >. Acesso em: 16 nov. 2017.

Habeas Corpus no 117.946/PR. Relator: Min. Luiz

Fux. Brasília, DF, 18 de dezembro de 2013. Disponível em: $<$ http://www.stf.jus.br/portal/processo/verProcessoAndamento.asp?numero=117946\&class $\mathrm{e}=\mathrm{HC} \&$ codigoClasse $=0 \&$ origem $=J U R \&$ recurso $=0 \&$ tipoJulgamento $=\mathrm{M}>$. Acesso em: 16 nov. 2017.

Habeas Corpus $n^{0}$ 119.976/SP. Relator: Min. Luiz

Fux. Brasília, DF, 25 de fevereiro de 2014. Disponível em: $<$ http://www.stf.jus.br/portal/processo/verProcessoPeca.asp?id=207749167\&tipoApp=.pdf >. Acesso em: 16 nov. 2017.

Habeas Corpus $\mathbf{n}^{0}$ 120.146/SP. Relator: Min. Dias Toffoli. Brasília, DF, 22 de abril de 2014. Disponível em: $<$ http://www.stf.jus.br/portal/processo/verProcessoPeca.asp?id=228930652\&tipoApp=.pdf >. Acesso em: 16 nov. 2017.

Ação Penal no 611/MG. Relator: Min. Luiz Fux.

Brasília, DF, 30 de setembro de 2014. Disponível em: <http://www.stf.jus.br/portal/processo/verProcessoPeca.asp?id=288028176\&tipoApp=.pdf >. Acesso em: 16 nov. 2017.

\section{Questão de Ordem no Inquérito no $3.815 / \mathrm{SP}$.}

Relator: Min. Marco Aurélio. Brasília, DF, 10 de fevereiro de 2015. Disponível em: < http://www.stf.jus.br/portal/processo/verProcessoPeca.asp?id=15325508516\&tipoApp=.pd f>. Acesso em: 16 nov. 2017.

Embargos de Declaração no Recurso Ordinário em

Habeas Corpus $\mathbf{n}^{\mathbf{0}}$ 124.192/PR. Relator: Min. Dias Toffoli. Brasília, DF, 28 de abril de 2015. em:

http://www.stf.jus.br/portal/processo/verProcessoPeca.asp?id=307006357\&tipoApp=.pdf $>$. Acesso em: 16 nov. 2017.

Inquérito no 3.204/SE. Relator: Min. Gilmar Mendes.

Brasília, DF, 23 de junho de 2015. Disponível em: < 
http://www.stf.jus.br/portal/processo/verProcessoPeca.asp?id=307222396\&tipoApp=.pdf $>$. Acesso em: 16 nov. 2017.

Habeas Corpus $\mathbf{n}^{\mathbf{0}}$ 127.221/SP. Relator: Min. Teori

Zavascki. Brasília, DF, 25 de agosto de 2015. Disponível em: < http://www.stf.jus.br/portal/processo/verProcessoPeca.asp?id=307678431\&tipoApp=.pdf $>$. Acesso em: 16 nov. 2017.

Habeas Corpus no 127.483/PR. Relator: Min. Dias

Toffoli. Brasília, DF, 27 de agosto de 2015. Disponível em: < http://www.stf.jus.br/portal/processo/verProcessoPeca.asp?id=308597935\&tipoApp=.pdf $>$. Acesso em: 16 nov. 2017.

Embargos de Declaração no Inquérito nº 3.204/SE.

Relator: Min. Gilmar Mendes. Brasília, DF, 20 de outubro de 2015. Disponível em: < http://www.stf.jus.br/portal/processo/verProcessoPeca.asp?id=308078800\&tipoApp=.pdf $>$. Acesso em: 16 nov. 2017.

Inquérito $n^{\mathbf{0}}$ 4.130/PR. Relator: Min. Dias Toffoli.

Brasília, DF, 03 de fevereiro de 2016. Disponível em: < http://www.stf.jus.br/portal/processo/verProcessoAndamento.asp?numero=4130\&classe=I nq-QO\& codigoClasse $=0 \&$ origem $=J U R \&$ recurso $=0 \&$ tipoJulgamento $=\mathrm{M}>$. Acesso em: 16 nov. 2017.

Ação Cautelar no 3.872/DF. Relator: Min. Edson

Fachin. Brasília, DF, 02 de março de 2016. Disponível em: < http://www.stf.jus.br/portal/processo/verProcessoAndamento.asp?numero=3872\&classe=A $\mathrm{C}-\mathrm{AgR} \&$ codigoClasse $=0 \&$ origem $=\mathrm{JUR} \&$ recurso $=0 \&$ tipoJulgamento $=\mathrm{M}>$. Acesso em: 16 nov. 2017.

Agravo Regimental na Reclamação no $22.009 / P R$.

Relator: Min. Teori Zavascki. Brasília, DF, 16 de fevereiro de 2016. Disponível em: < http://www.stf.jus.br/portal/processo/verProcessoPeca.asp?id=309467822\&tipoApp=.pdf $>$. Acesso em: 16 nov. 2017.

Habeas Corpus no 132.143/MT. Relator: Min. Edson

Fachin. Brasília, DF, 15 de março de 2016. Disponível em: < 
http://www.stf.jus.br/portal/processo/verProcessoPeca.asp?id=311484250\&tipoApp=.pdf $>$. Acesso em: 16 nov. 2017.

Agravo Regimental na Petição no 5.885/DF. Relator:

Min. Teori Zavascki. Brasília, DF, 05 de abril de 2016. Disponível em: < http://www.stf.jus.br/portal/processo/verProcessoPeca.asp?id=309286577\&tipoApp=.pdf $>$. Acesso em: 16 nov. 2017.

Medida Cautelar em Mandado de Segurança $\mathbf{n}^{\circ}$

34.130/DF. Relator: Min. Edson Fachin. Brasília, DF, 14 de abril de 2016. Disponível em: <http://www.stf.jus.br/portal/processo/verProcessoPeca.asp?id=310206700\&tipoApp=.pdf >. Acesso em: 16 nov. 2017.

Reclamação $\mathbf{n}^{\circ}$ 21.258/PR. Relator: Min. Dias

Toffoli. Brasília, DF, 20 de abril de 2016. Disponível em: < http://www.stf.jus.br/portal/processo/verProcessoAndamento.asp?numero=21258\&classe= Rcl-AgR\&codigoClasse $=0 \&$ origem $=J U R \&$ recurso $=0 \&$ tipoJulgamento $=\mathrm{M}>$. Acesso em: 16 nov. 2017.

Embargos de Declaração no Inquérito no 3.983/DF.

Relator: Min. Teori Zavascki. Brasília, DF, 02 de junho de 2016. Disponível em: < http://www.stf.jus.br/portal/processo/verProcessoPeca.asp?id=310475709\&tipoApp=.pdf $>$. Acesso em: 16 nov. 2017.

Agravo Regimental na Petição no 6.164/DF. Relator: Min. Teori Zavascki. Brasília, DF, 06 de setembro de 2016. Disponível em: < http://www.stf.jus.br/portal/processo/verProcessoPeca.asp?id=310330067\&tipoApp=.pdf $>$. Acesso em: 16 nov. 2017.

Inquérito n⿳ 4.146/DF. Relator: Min. Teori Zavascki.

Brasília, DF, 05 de outubro de 2016. Disponível em: < http://www.stf.jus.br/portal/processo/verProcessoAndamento.asp?numero=4146\&classe=I nq\& codigoClasse $=0$ \&origem $=J U R \&$ recurso $=0 \&$ tipoJulgamento $=M>$. Acesso em: 16 nov. 2017.

\section{Agravo Regimental no Habeas Corpus $\mathbf{n}^{\circ}$}

134.190/SP. Relator: Min. Gilmar Mendes. Brasília, DF, 09 de novembro de 2016. Disponível em: 
http://www.stf.jus.br/portal/processo/verProcessoPeca.asp?id=310776082\&tipoApp=.pdf $>$. Acesso em: 16 nov. 2017.

Reclamação no 24.116/SP. Relator: Min. Gilmar

Mendes. Brasília, DF, 13 de dezembro de 2016. Disponível em: < http://www.stf.jus.br/portal/processo/verProcessoPeca.asp?id=311194065\&tipoApp=.pdf $>$. Acesso em: 16 nov. 2017.

Agravo Regimental na Petição no 6.351/DF. Relator: Min. Edson Fachin. Brasília, DF, 07 de fevereiro de 2017. Disponível em: < http://www.stf.jus.br/portal/processo/verProcessoPeca.asp?id=311245106\&tipoApp=.pdf $>$. Acesso em: 16 nov. 2017.

Embargos de Declaração no Inquérito no 3.984/DF.

Relator: Min. Edson Fachin. Brasília, DF, 14 de fevereiro de 2017. Disponível em: < http://www.stf.jus.br/portal/processo/verProcessoPeca.asp?id=311405603\&tipoApp=.pdf $>$. Acesso em: 16 nov. 2017.

Segundos Embargos de Declaração no Inquérito $\mathbf{n}^{\circ}$

3.984/DF. Relator: Min. Edson Fachin. Brasília, DF, 14 de fevereiro de 2017. Disponível em: <http://www.stf.jus.br/portal/processo/verProcessoPeca.asp?id=311405701\&tipoApp $=. p d f>$. Acesso em: 16 nov. 2017.

Embargos de Declaração no Inquérito no 3.979/DF.

Relator: Min. Edson Fachin. Brasília, DF, 21 de fevereiro de 2017. Disponível em: < http://www.stf.jus.br/portal/processo/verProcessoPeca.asp?id=311474593\& tipoApp=.pdf $>$. Acesso em: 16 nov. 2017.

Agravo Regimental na Petição no 6.138/DF. Relator: Min. Edson Fachin. Brasília, DF, 21 de fevereiro de 2017. Disponível em: < http://www.stf.jus.br/portal/processo/verProcessoPeca.asp?id=312641519\&tipoApp=.pdf $>$. Acesso em: 16 nov. 2017.

\section{Segundo Agravo Regimental na Petição no}

6.138/DF. Relator: Min. Edson Fachin. Brasília, DF, 21 de fevereiro de 2017. Disponível em: < http://www.stf.jus.br/portal/processo/verProcessoPeca.asp?id=312642102\&tipo App=.pdf $>$. Acesso em: 16 nov. 2017. 
Inquérito no 3.982/DF. Relator: Min. Edson Fachin.

Brasília, DF, 07 de março de 2017. Disponível em: $<$ http://www.stf.jus.br/portal/processo/verProcessoPeca.asp?id=311943949\&tipoApp=.pdf >. Acesso em: 16 nov. 2017.

Habeas Corpus $n^{0}$ 129.887/RJ. Relator: Min. Marco

Aurélio. Brasília, DF, 18 de abril de 2017. Disponível em: <http://www.stf.jus.br/portal/processo/verProcessoPeca.asp?id=312161444\&tipoApp;=.pdf >. Acesso em: 16 nov. 2017.

Habeas Corpus n 138.207/PR. Relator: Min. Edson

Fachin. Brasília, DF, 25 de abril de 2017. Disponível em: $<$ http://www.stf.jus.br/portal/processo/verProcessoPeca.asp?id=312859280\&tipoApp=.pdf >. Acesso em: 16 nov. 2017.

Agravo Regimental no Inquérito $n^{0}$ 4.419/DF.

Relator: Min. Edson Fachin. Brasília, DF, 13 de junho de 2017. Disponível em: $<$ http://www.stf.jus.br/portal/processo/verProcessoPeca.asp?id=312063708\&tipoApp=.pdf >. Acesso em: 16 nov. 2017.

Agravo Regimental na Petição nº 6.631/DF. Relator:

Min. Edson Fachin. Brasília, DF, 13 de junho de 2017. Disponível em: $<$ http://www.stf.jus.br/portal/processo/verProcessoPeca.asp?id=312063503\&tipoApp=.pdf >. Acesso em: 16 nov. 2017.

Agravo Regimental no Inquérito $n^{0} 4.415 / \mathrm{DF}$.

Relator: Min. Edson Fachin. Brasília, DF, 15 de agosto de 2017. Disponível em: $<$ http://www.stf.jus.br/portal/processo/verProcessoAndamento.asp?numero $=4415 \&$ classe $=$ Inq-AgR \& codigoClasse $=0 \&$ origem $=J U R \&$ recurso $=0 \&$ tipoJulgamento $=\mathrm{M}>$. Acesso em: 28 mar. 2018.

Agravo Regimental na Petição no 6.727/DF. Relator:

Min. Edson Fachin. Brasília, DF, 30 de junho de 2017. Disponível em: $<$ http://www.stf.jus.br/portal/processo/verProcessoPeca.asp?id=312324378\&tipoApp=.pdf >. Acesso em: 16 nov. 2017.

Petição no 7.075/DF. Relator: Min. Edson Fachin. Brasília, DF, 15 de agosto de 2017. Disponível em: 
<http://www.stf.jus.br/portal/processo/verProcessoPeca.asp?id=312892534\&tipoApp=.pdf >. Acesso em: 16 nov. 2017.

Petição no 7.076/DF. Relator: Min. Edson Fachin.

Brasília, DF, 15 de agosto de 2017. Disponível em: $<$ http://www.stf.jus.br/portal/processo/verProcessoAndamento.asp?numero=7076\&classe= Pet\&codigoClasse $=0 \&$ origem $=J U R \&$ recurso $=0 \&$ tipoJulgamento $=\mathrm{M}>$. Acesso em: 28 mar. 2018.

Inquérito nº 4.112/DF. Relator: Min. Edson Fachin. Brasília, DF, 22 de agosto de 2017. Disponível em: < http://www.stf.jus.br/portal/processo/verProcessoAndamento.asp?numero=4112\&classe=I nq\& codigoClasse $=0 \&$ origem $=J U R \&$ recurso $=0 \&$ tipoJulgamento $=M>$. Acesso em: 28 mar. 2018.

Agravo Regimental na Petição no 6.667/DF. Relator:

Min. Edson Fachin. Brasília, DF, 25 de agosto de 2017. Disponível em: $<$ http://www.stf.jus.br/portal/processo/verProcessoPeca.asp?id=312638934\&tipoApp=.pdf >. Acesso em: 16 nov. 2017.

Agravo Regimental na Petição no 6.734/DF. Relator:

Min. Edson Fachin. Brasília, DF, 29 de agosto de 2017. Disponível em: $<$ http://www.stf.jus.br/portal/processo/verProcessoPeca.asp?id=312744627\&tipoApp=.pdf >. Acesso em: 16 nov. 2017.

\section{Agravo Regimental no Inquérito $\mathrm{n}^{\circ} 4.435 / \mathrm{DF}$.}

Relator: Min. Marco Aurélio. Brasília, DF, 12 de setembro de 2017. Disponível em: < http://www.stf.jus.br/portal/processo/verProcessoAndamento.asp?numero=4435\&classe=I nq-AgR \& codigoClasse $=0 \&$ origem $=J U R \&$ recurso $=0 \&$ tipoJulgamento $=M>$. Acesso em: 28 mar. 2018.

\section{Segundo Agravo Regimental na Petição no}

6.714/DF. Relator: Min. Edson Fachin. Brasília, DF, 15 de setembro de 2017. Disponível em:

<http://www.stf.jus.br/portal/processo/verProcessoPeca.asp?id=312811064\&tipoApp=.pdf >. Acesso em: 16 nov. 2017. 
Embargos de Declaração no Agravo Regimental na

Petição nº 6.840/DF. Relator: Min. Edson Fachin. Brasília, DF, 19 de setembro de 2017. Disponível

em:

$<$ http://www.stf.jus.br/portal/processo/verProcessoPeca.asp?id=312859819\&tipoApp=.pdf

>. Acesso em: 16 nov. 2017.

Agravo Regimental na Petição no 6.643/PR. Relator:

Min. Edson Fachin. Brasília, DF, 19 de setembro de 2017. Disponível em: <http://www.stf.jus.br/portal/processo/verProcessoPeca.asp?id=312082211\&tipoApp;=.pdf >. Acesso em: 16 nov. 2017.

Segundo Agravo Regimental na Reclamação $\mathbf{n}^{\circ}$

23.396/PR. Relator: Min. Gilmar Mendes. Brasília, DF, 19 de setembro de 2017. Disponível em: <http://www.stf.jus.br/portal/processo/verProcessoPeca.asp?id=3128 79528\& tipoApp=.pdf>. Acesso em: 16 nov. 2017.

. Embargos de Declaração no Inquérito n 3.990/DF.

Relator: Min. Edson Fachin. Brasília, DF, 19 de setembro de 2017. Disponível em: <http://www.stf.jus.br/portal/processo/verProcessoPeca.asp?id=312851196\&tipoApp=.pdf >. Acesso em: 16 nov. 2017.

Segundos Embargos de Declaração no Inquérito $\mathbf{n}^{0}$

3.990/DF. Relator: Min. Edson Fachin. Brasília, DF, 19 de setembro de 2017. Disponível em:

<http://www.stf.jus.br/portal/processo/verProcessoPeca.asp?id=312851224\&tipoApp=.pdf >. Acesso em: 16 nov. 2017.

Terceiros Embargos de Declaração no Inquérito no

3.990/DF. Relator: Min. Edson Fachin. Brasília, DF, 19 de setembro de 2017. Disponível em:

$<$ http://www.stf.jus.br/portal/processo/verProcessoPeca.asp?id=312851485\&tipoApp=.pdf >. Acesso em: 16 nov. 2017.

Quartos Embargos de Declaração no Inquérito no

3.990/DF. Relator: Min. Edson Fachin. Brasília, DF, 19 de setembro de 2017. Disponível em: 
<http://www.stf.jus.br/portal/processo/verProcessoPeca.asp?id=312851557\&tipoApp=.pdf >. Acesso em: 16 nov. 2017.

Ação Penal no 676/MT. Relator: Min. Rosa Weber.

Brasília, DF, 17 de outubro de 2017. Disponível em: < http://www.stf.jus.br/portal/processo/verProcessoAndamento.asp?numero=676\&classe=A $\mathrm{P} \&$ codigoClasse $=0 \&$ origem $=J U R \&$ recurso $=0 \&$ tipoJulgamento $=\mathrm{M}>$. Acesso em: 28 mar. 2018.

Quarto Agravo Regimental na Petição no 6.780/DF.

Relator: Min. Edson Fachin. Brasília, DF, 20 de outubro de 2017. Disponível em: < http://www.stf.jus.br/portal/processo/verProcessoAndamento.asp?numero=6780\&classe $=\mathrm{P}$ et $-\mathrm{AgR}$-quarto\&codigoClasse $=0$ \&origem $=\mathrm{JUR} \&$ recurso $=0 \&$ tipoJulgamento $=\mathrm{M}>$. Acesso em: 28 mar. 2018.

Ação Penal no 694/MT. Relator: Min. Rosa Weber.

Brasília, DF, 14 de novembro de 2017. Disponível em: $<$ http://www.stf.jus.br/portal/processo/verProcessoAndamento.asp?numero=694\&classe= AP\&codigoClasse $=0 \&$ origem $=J U R \&$ recurso $=0 \&$ tipoJulgamento $=M>$. Acesso em: 16 nov. 2017.

Inquérito $n^{0}$ 4.141/DF. Relator: Min. Luís Roberto Barroso. Brasília, DF, 12 de dezembro de 2017. Disponível em: < http://stf.jus.br/portal/processo/verProcessoAndamento.asp?numero=4141\&classe=Inq\&co digoClasse $=0 \&$ origem $=J U R \&$ recurso $=0 \&$ tipoJulgamento $=\mathrm{M}>$. Acesso em: 28 mar. 2018. Inquérito no 3.998/DF. Relator: Min. Edson Fachin. Brasília, DF, 18 de dezembro de 2017. Disponível em: < http://www.stf.jus.br/portal/processo/verProcessoAndamento.asp?numero=3998\&classe=I nq\&codigoClasse $=0 \&$ origem $=J U R \&$ recurso $=0 \&$ tipoJulgamento $=M>$. Acesso em: 28 mar. 2018.

\section{Embargos de Declaração no Agravo Regimental na}

Petição nº 6.820/DF. Relator: Min. Edson Fachin. Brasília, DF, 06 de fevereiro de 2018. Disponível em:

http://stf.jus.br/portal/processo/verProcessoAndamento.asp?numero=6820\&classe=Pet- 
AgR-ED\&codigoClasse $=0 \&$ origem $=J U R \&$ recurso $=0 \&$ tipoJulgamento $=\mathrm{M}>$. Acesso em: 28 mar. 2018.

FREIRE JÚNIOR, Américo Bedê; DEZAN, Willy Potrich da Silva. Delação premiada e direitos fundamentais do sujeito passivo da persecução penal a partir da regulamentação constante na lei 12.850/2013. Revista eletrônica de Direito Processual, Rio de Janeiro, ano 11, v.18, n.1, p. 42-67, jan./abr. 2017.

JARDIM, Afranio Silva. A influência norte-americana nos sistemas processuais penais latinos. Revista eletrônica de direito processual. Rio de Janeiro. Ano 10, v.17, n.2, jul./dez. 2016. $\quad$ p. $\quad$ 02-10. Disponível em: $<$ http://www.epublicacoes.uerj.br/index.php/redp/article/view/26598/18956>. Acesso em: 25 jul. 2018.

NASCIMENTO, Carlos Valder do. Abuso do exercício do direito: responsabilidade pessoal. 2.ed. São Paulo: Saraiva, 2015.

NEVES, Guilherme Pimenta da Veiga. Das normas fundamentais do Processo Civil: arts.

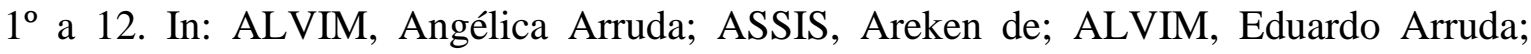
LEITE, George Salomão (Coord.). Comentários ao Código de Processo Civil. São Paulo: Saraiva, 2016.

SANTOS, Marcos Paulo Dutra. Colaboração (delação) premiada. $2^{\mathrm{a}}$ ed. Salvador: JusPodivm, 2017a.

- Colaboração unilateral premiada como consectário lógico das balizas constitucionais do devido processo legal brasileiro. Revista brasileira de Direito Processual Penal, Porto Alegre, v. 3, n. 1, p. 131-166, jan./abr. 2017b. Disponível em: < http://www.ibraspp.com.br/revista/index.php/RBDPP/article/view/49/55>. Acesso em: 02 out. 2017.

SENNA, Andressa Paula. O abuso de direito e a litigância de má-fé como impeditivos à marcha processual e ao resultado justo da prestação jurisdicional. Revista de Direito Privado, São Paulo, v. 40, p. 9-59, out./dez. 2009.

SILVA, Marcelo R. A colaboração premiada como terceira via do direito penal no enfrentamento à corrupção administrativa organizada, Revista brasileira de Direito Processual Penal, Porto Alegre, v.3, n.1, p. 285-314, jan./abr. 2017.

SOUZA, Alexander Araújo de. O abuso do Direito no Processo Penal. Rio de Janeiro: Lumen Juris, 2007a. 
Rio de Janeiro. Ano 13. Volume 20. Número 3. Setembro a Dezembro de 2019

Periódico Quadrimestral da Pós-Graduação Stricto Sensu em Direito Processual da UERJ

Patrono: José Carlos Barbosa Moreira (in mem.). ISSN 1982-7636. pp. 323-357 www.redp.uerj.br

O abuso do direito no requerimento de medidas cautelares típicas e atípicas no processo penal. Revista dos Tribunais, São Paulo, v. 856, p. 470-492, fev. 2007b.

SUXBERGER, Antônio Henrique Graciano; MELLO, Gabriela Starling Jorge Vieira de. A voluntariedade da colaboração premiada e sua relação com a prisão processual do colaborador. Revista brasileira de Direito Processual Penal, Porto Alegre, v. 3, n. 1, p. 189-224, jan./abr. 2017. Disponível em: http://www.ibraspp.com.br/revista/index.php/RBDPP/article/view/40/57>. Acesso em: 02 out. 2017.

TARUFFO, Michele. Abuso de direitos processuais: padrões comparativos de lealdade processual (relatório geral). Revista de Processo, São Paulo, v. 177, a. 34, p. 153-183, jul. 2009.

Abuso del Processo. Revista de Processo Comparado, São Paulo, v. 5, p. 141-156, jan./jun. 2017.

\section{LISTA DE ANEXOS}

\begin{tabular}{|c|c|c|c|}
\hline $\mathrm{N}^{\circ}$ PROCESSO & ESPÉCIE DE AÇÃO/RECURSO & TIPO DE ABUSO & TEOR DO PROBLEMA \\
\hline HC 108716 & HABEAS CORPUS & AAA & REDISCUSSÃO DE MATÉRIA FÁTICA \\
\hline HC 109043 & HABEAS CORPUS & AAA & REDISCUSSÃO DE MATÉRIA FÁTICA \\
\hline HC 127221 & HABEAS CORPUS & AAA & REDISCUSSÃO DE MATÉRIA FÁTICA \\
\hline HC 132143 & HABEAS CORPUS & $\mathrm{AAA}$ & HC CONTRÁRIO À SÚMULA \\
\hline HC 133600 & HABEAS CORPUS & AAA & HC CONTRÁRIO À SÚMULA \\
\hline HC $134190 \mathrm{AgR}$ & AGRA VO REGIMENTAL & AAR & REDISCUSSÃO DE MATÉRIA FÁTICA \\
\hline Inq 3204 & INQUÉRITO & ADA e ADD & $\begin{array}{l}\text { CORRÉU ALEGOU NULIDADE DA CITAÇÃO APESAR DE SE } \\
\text { OCULTAR PARA NÃO RECEBE-LA; UM DOS CORREUS FOI } \\
\text { DENUNCIADO SEM JUSTA CAUSA DA SUA PARTICIPAÇÃO }\end{array}$ \\
\hline Inq $3815 \mathrm{QO}$ & QUESTÃO DE ORDEM & $\mathrm{ADA}$ & $\begin{array}{l}\text { ARQUIVAMENTO DO INQUÉRITO DOS DOIS CORREUS } \\
\text { RESTANTES EM FACE DA DELAÇÃO NÃO TRAZER } \\
\text { ELEMENTOS MIINIMOS PARA O ACEITE DA DENÚNCIA }\end{array}$ \\
\hline Inq 3979 & EMBARGOS DE DECLARAÇÃO & AAR & REDISCUSSÃO DE MATÉRIA FÁTICA \\
\hline Inq 3983 & EMBARGOS DE DECLARAÇÃO & AAR & REDISCUSSÃO DE MATÉRIA FÁTICA \\
\hline Inq $3984 \mathrm{ED}$ & EMBARGOS DE DECLARAÇÃO & AAR & REDISCUSSÃO DE MATÉRIA FÁTICA \\
\hline Inq 3984 & EMBARGOS DE DECLARAÇÃO & AAR & REDISCUSSÃO DE MATÉRIA FÁTICA \\
\hline Inq 3990 & EMBARGOS DE DECLARAÇÃO & AAR & REDISCUSSÃO DE MATÉRIA FÁTICA \\
\hline Inq 3990 & EMBARGOS DE DECLARAÇÃO (SEGUNDO) & AAR & REDISCUSSÃO DE MATÉRIA FÁTICA \\
\hline Inq 3990 & EMBARGOS DE DECLARAÇÃO (TERCEIRO) & AAR & REDISCUSSÃO DE MATÉRIA FÁTICA \\
\hline Inq 3990 & EMBARGOS DE DECLARAÇÃO (QUARTO) & AAR & REDISCUSSÃO DE MATÉRIA FÁTICA \\
\hline Inq 3998 & INQUÉRITO & $\mathrm{ADA}$ & DENÚNCIA SEM CONTEÚDO PROBATÓRIO MÍNIMO \\
\hline Inq 4112 & INQUÉRITO & $\mathrm{ADA}$ & DENÚNCIA SEM CONTEÚDO PROBATÓRIO MÍNIMO \\
\hline Pet $6840 \mathrm{AgR}$ & EMBARGOS DE DECLARAÇÃO & AAR & REDISCUSSÃO DE MATÉRIA FÁTICA \\
\hline RHC 116108 & RECURSO ORDINÁRIO & AAR & $\begin{array}{l}\text { BUSCAR REVISÃO CRIMINAL MEDIANTE RECURSO } \\
\text { ORDINÁRIO }\end{array}$ \\
\hline RHC 124192 & EMBARGOS DE DECLARAÇÃO & AAR & REDISCUSSÃO DE MATÉRIA FÁTICA \\
\hline
\end{tabular}

Tabela 1: Tipos de Abuso de Direito em julgados do colegiado do STF no período de $16 / 09 / 2013$ a 28/03/2018. 
Revista Eletrônica de Direito Processual - REDP.

Rio de Janeiro. Ano 13. Volume 20. Número 3. Setembro a Dezembro de 2019

Periódico Quadrimestral da Pós-Graduação Stricto Sensu em Direito Processual da UERJ

Patrono: José Carlos Barbosa Moreira (in mem.). ISSN 1982-7636. pp. 323-357

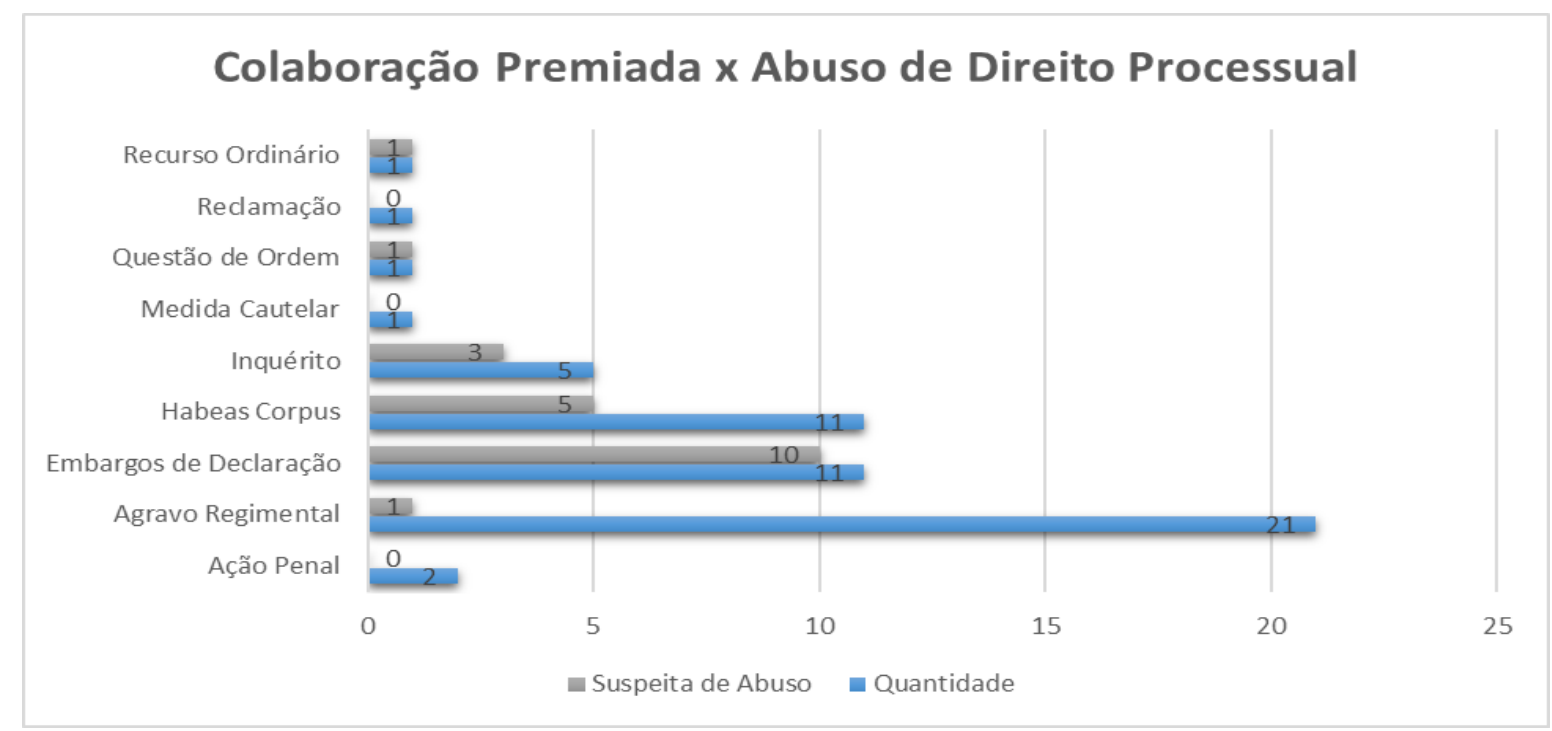

Gráfico 1: Relação entre a distribuição por tipo de demandas envolvendo colaborações premiadas julgadas pelo STF (período de 16/09/2013 a 28/03/2018) e possíveis abusos de direito processual.

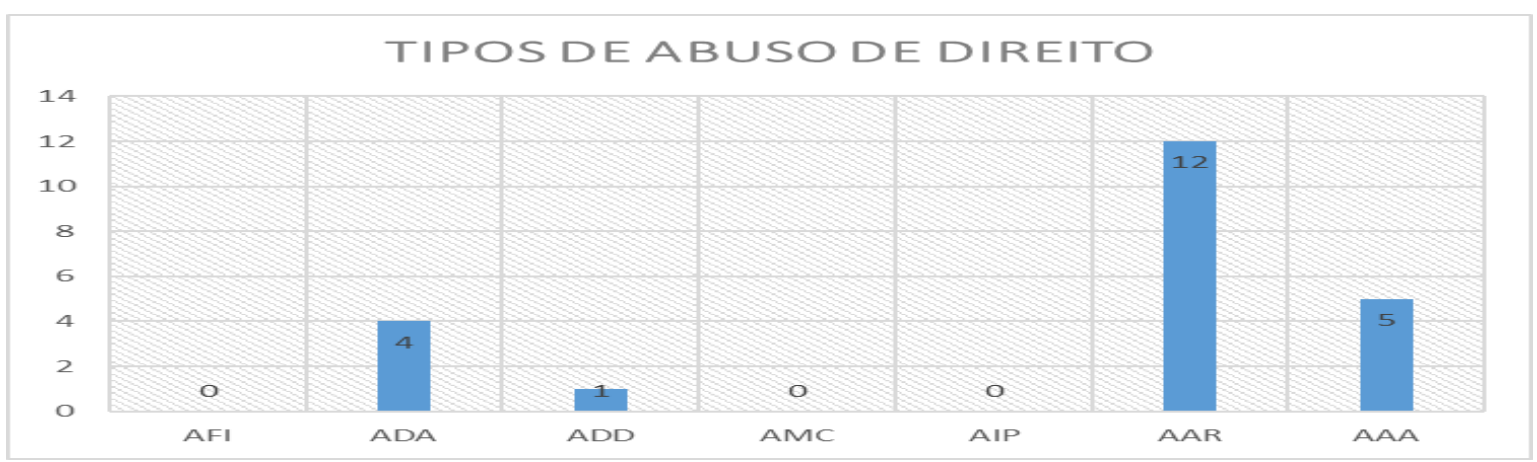

Gráfico 2: Tipos de Abuso de Direito em julgados do colegiado do STF no período de $16 / 09 / 2013$ a 28/03/2018.

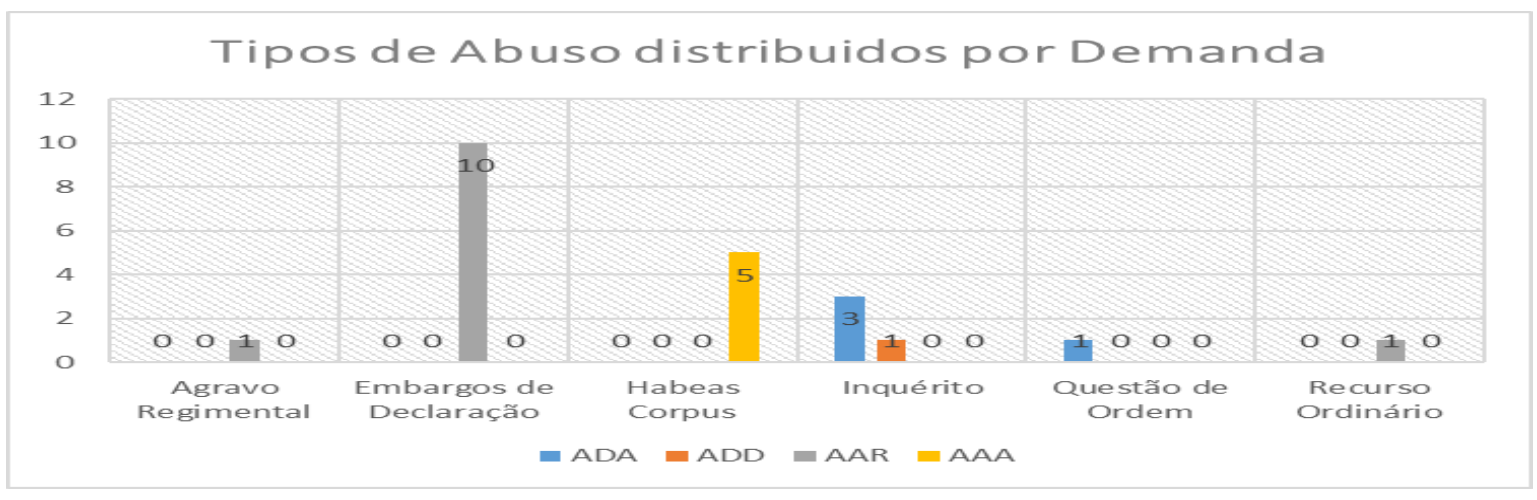


Revista Eletrônica de Direito Processual - REDP.

Rio de Janeiro. Ano 13. Volume 20. Número 3. Setembro a Dezembro de 2019

Periódico Quadrimestral da Pós-Graduação Stricto Sensu em Direito Processual da UERJ

Patrono: José Carlos Barbosa Moreira (in mem.). ISSN 1982-7636. pp. 323-357 www.redp.uerj.br

Gráfico 3: Tipos de Abuso de Direito distribuídos por demanda em julgados do colegiado do STF no período de 16/09/2013 a 28/03/2018.

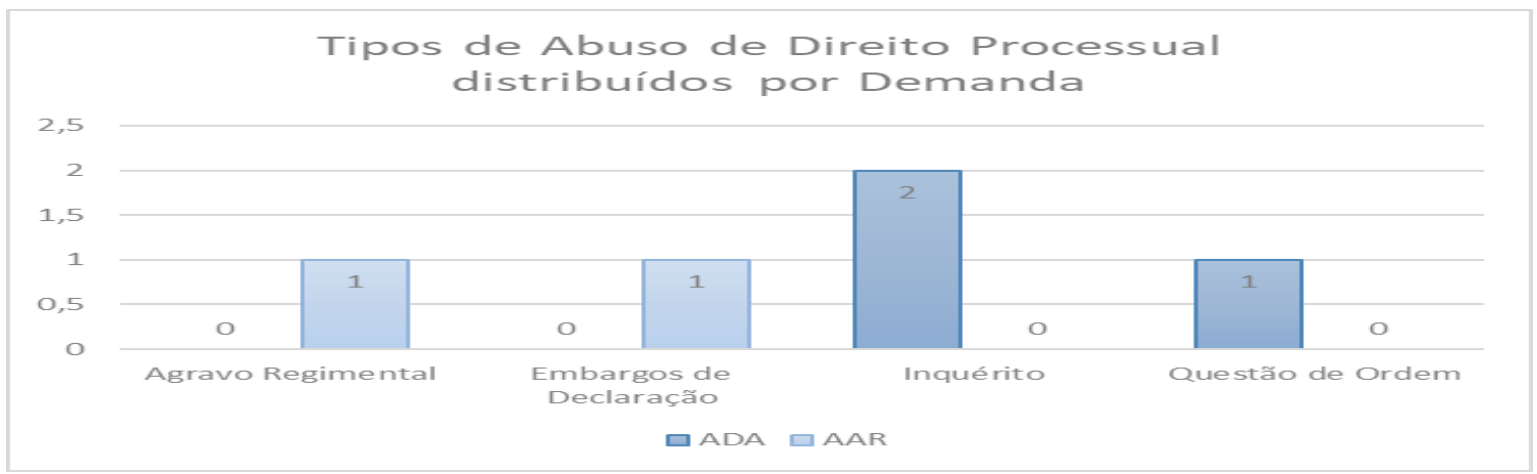

Gráfico 4: Tipos de Abuso de Direito distribuídos por demanda cuja colaboração premiada constitui uma das matérias principais em julgados do colegiado do STF no período de $16 / 09 / 2013$ a 28/03/2018. 